\title{
POMIARY IZOLACYJNOŚCI AKUSTYCZNEJ WYBRANYCH ŚCIAN ZEWNECTRZNYCH W BUDYNKU WIELKOPLYTOWYM PRZED I PO DOCIEPLENIU
}

\begin{abstract}
W artykule zawarto wyniki badań izolacyjności akustycznej przegród zewnętrznych budynku z tzw. wielkiej płyty. Badania wykonano zgodnie z obowiązującymi normami. O wpływie docieplenia na izolacyjność akustyczną przegrody jednowarstwowej pisano już wielokrotnie. Analizy dokonywano wówczas na podstawie badań laboratoryjnych. Jednak aby sprawdzić, jaki wpływ na izolacyjność akustyczną ścian zewnętrznych z ,wielkiej płyty" ma ich docieplenie, dokonano pomiarów w przykładowym mieszkaniu. Badania wykonano w budynku mieszkalnym wielorodzinnym zbudowanym $\mathrm{w}$ technologii WUFT (ściana trójwarstwowa). Pomiary wykonano w dwóch wariantach: przed i po dociepleniu ścian styropianem grubości $8 \mathrm{~cm}$. Badano ściany z oknami oraz ścianę pełną pokoju, sąsiadującą ze ścianą $\mathrm{z}$ oknem. W celu zminimalizowania wpływu okien, wykonano również pomiary po zaizolowaniu ich płytami z wełny mineralnej, które układano warstwami naprzemiennie. Następnie przedstawiono wyniki i dokonano ich analizy. Docieplenie ma wpływ na izolacyjność akustyczną przegrody. Drugim elementem analizy w aspekcie izolacyjności akustycznej było określenie wpływu okien.
\end{abstract}

Słowa kluczowe: izolacyjność akustyczna, ciśnienie akustyczne, decybel, wielka płyta, WUFT

\section{Wstęp}

Zmieniające się wciąż, a ponadto coraz ostrzejsze wymagania europejskie skierowane ku oszczędności energii powodują istotne zmiany w różnych działaniach i przepisach obejmujących sektor budownictwa. Odniesieniem tych działań, w tym tzw. idei energooszczędności, są nowe technologie wznoszenia budynków jak również podejmowanie zabiegów termoizolacyjnych w budynkach już istniejących. Odzwierciedleniem tych idei są również kolejne nowelizacje przepisów w tym: „Prawo Budowlanego” [7], „Warunki Techniczne, jakim po-

\footnotetext{
${ }^{1}$ Kinga Zębala, Politechnika Krakowska, Wydział Inżynierii Lądowej, Instytut Materiałów i Konstrukcji Budowlanych, Zakład Budownictwa i Fizyki Budowli, ul. Warszawska 24, 31-155 Kraków; tel. 12 628-20-25 w.2384; kzebala@pk.edu.pl
} 
winny odpowiadać budynki i ich usytuowanie" [8], jak również uznawanie przez Polskę różnego rodzaju przepisów dotyczących energooszczędności. W aspekcie powyższego powszechnie porusza się kwestię budowy przegród zewnętrznych budynku w kontekście energooszczędności, a wręcz do rzadkości należy dobór i analiza przegród pod względem wymagań i właściwości akustycznych [5].

W ramach prowadzonych badań własnych w latach 2009-2015 obejmujących korelację pomiędzy izolacyjnością termiczną a akustyczną i przedstawionych w pracy [1] oraz [2] wykazano wyraźnie nieliniową zależność pomiędzy grubością izolacji a parametrami akustycznymi. Ponadto na podstawie wyników analityczno-badawczych w ww. pracach stwierdzono, że w odniesieniu do zastosowanego materiału w przegrodzie występuje ujemna korelacja pomiędzy oporem cieplnym, a wskaźnikami izolacyjności akustycznej $\mathrm{R}_{\mathrm{W}}$ i $\mathrm{R}_{\mathrm{A}, 2}$. Poziom tej korelacji w znacznej mierze zależny jest od grupy materiałowej - silniejsza występuje dla materiałów porowatych, słabsza dla materiałów zwięzłych. Silna zależność występuje również w ścianach, w których stosuje się materiał izolacyjny. Wykazany w pracach $[1,2]$ wpływ ocieplenia zależny jest nie tylko od rodzaju materiału, z którego wykonana jest termoizolacja i od sposobu jego mocowania (rodzaju systemu), ale także od jakości (dokładności) wykonawczej. W przeprowadzonych badaniach dla samego systemu ETICS, zwanego wcześniej metodą „lekką mokrą" (w różnych wariantach materiałowych) stwierdzono spadek izolacyjności akustycznej $\mathrm{R}_{\mathrm{W}}$ o $2 \div 5 \mathrm{~dB}$ i $\mathrm{R}_{\mathrm{A}, 2}$ o $2 \div 4 \mathrm{~dB}$.

W kontekście przeprowadzonych analiz jak również uzyskanych wyników podjęto próbę określenia parametrów akustycznych przegrody $\mathrm{w}$ warunkach „in situ”. Do badań wybrano obiekt istniejący, wykonany w tzw. technologii wielkopłytowej, który poddawany był zabiegom dociepleniowym. Do badań przyjęto ścianę pełną oraz ścianę otworową (okienną). Badania przeprowadzono w dwóch wariantach budowy przegrody - w warunkach naturalnych oraz po zabiegu termomodernizacyjnym. Wyniki oraz wnioski z prowadzanych badań przedstawiono w dalszej części artykułu.

\section{Izolacyjność akustyczna - informacje podstawowe}

Izolacyjność akustyczna jest miarą określającą jak dobrze konstrukcja budowlana (przegroda) izoluje pomieszczenie od dźwięków pochodzących z innych pomieszczeń lub z otoczenia. Wyróżnia się izolacyjność akustyczną od dźwięków powietrznych (przechodzących przez ściany, stropy i instalacje) oraz od dźwięków uderzeniowych (przenoszonych przez stropy i instalacje), w których stosuje się odpowiednio:

- do oceny izolacyjności akustycznej od dźwięków uderzeniowych parametr $\mathrm{L}_{\mathrm{nT}}$,

- do oceny izolacyjności akustycznej od dźwięków powietrznych, w przypadku ścian zewnętrznych, stosuje się parametr $\mathrm{R}_{\mathrm{A}, 2}$, który uwzględnia widmo typowego hałasu zewnętrznego. 
Pomocnym jest również tzw. wskaźnik ważony $\mathrm{R}_{\mathrm{w}}$, który odnosi się do hałasu o równym poziomie $\mathrm{w}$ poszczególnych częstotliwościach. Jest wyrażany $\mathrm{w} \mathrm{dB}$ (decybel). Zgodnie z ISO 717-1 [7] można w uproszczeniu przyjąć, że wykorzystujemy wskaźnik oceny izolacyjności akustycznej właściwej $\mathrm{R}_{\mathrm{A}, 1}$ dla oceny ścian wewnętrznych i $\mathrm{R}_{\mathrm{A}, 2}$ dla oceny ścian zewnętrznych [6]. Zależności pomiędzy tymi wielkościami kształtują się następująco:

$$
\begin{aligned}
& \mathrm{R}_{\mathrm{A}, 1}=\mathrm{R}_{\mathrm{W}}+\mathrm{C}[\mathrm{dB}] \\
& \mathrm{R}_{\mathrm{A}, 2}=\mathrm{R}_{\mathrm{W}}+\mathrm{C}_{\mathrm{tr}}[\mathrm{dB}] \\
& \mathrm{R}_{\mathrm{W}}\left(\mathrm{C}, \mathrm{C}_{\mathrm{tr}}\right)[\mathrm{dB}]
\end{aligned}
$$

gdzie:

C - widmowy wskaźnik adaptacyjny - dotyczący hałasów użytkowych (rozmowa, muzyka, zabawa dzieci),

$\mathrm{C}_{\mathrm{tr}}$ - widmowy wskaźnik adaptacyjny - dotyczący transportu (ruch uliczny i kolejowy, samoloty itp.).

Wskaźniki C i $\mathrm{C}_{\text {tr }}$ przybierają wartości ujemne (a jedynie w nielicznych przypadkach wynoszą 0 ).

\section{Pomiary oraz analiza izolacyjności akustycznej przegrody przyjętej do badań}

\subsection{Charakterystyka budynku}

Badania terenowe wykonano $\mathrm{w}$ budynku mieszkalnym wielorodzinnym pięciokondygnacyjnym wykonanym $w$ technologii WUFT -87 GT na terenie miasta Kraków. Do badań przyjęto lokal znajdujący się na parterze, ze względu na swobodę dostępu do przegrody od strony zewnętrznej, w którym analizie poddano dwie ściany zewnętrzne - pełną oraz $\mathrm{z}$ otworami (rys.1). System WUFT-87 GT należy do grupy budynków tzw. wielkoformatowych, w którym ściany zewnętrzne były przygotowywane jako elementy trójwarstwowe, w pełni wykończone. Występujące w nim ściany o wysokości kondygnacji występowały najczęściej w sześćdziesięciocentymetrowych wymiarach modułowych np. szerokości 300, 480 i $600 \mathrm{~cm}$. Ostatni wymiar (600) dotyczył zazwyczaj ścian obejmujących dwa przylegające pomieszczenia - pokój i kuchnię. Wszystkie elementy ścienne maja grubość $25 \mathrm{~cm}$ i pozwalają na oparcie stropu na każdej $\mathrm{z}$ nich (w przeciwieństwie do systemu W-70 gdzie ściana zewnętrzna z otworami stanowi jedynie element osłonowy). W ścianie badanego budynku przyjęto (na podstawie dokumentacji technicznej) następujący układ warstw:

1. przed dociepleniem:

- $14 \mathrm{~cm}$ wewnętrzna warstwa konstrukcyjna $\mathrm{z}$ betonu,

$-5 \mathrm{~cm}$ warstwa izolacji cieplnej ze styropianu, 
- $6 \mathrm{~cm}$ zewnętrzna warstwa fakturowa $\mathrm{z}$ betonu;

2. po dociepleniu:

- $14 \mathrm{~cm}$ wewnętrzna warstwa konstrukcyjna $\mathrm{z}$ betonu,

$-5 \mathrm{~cm}$ warstwa izolacji cieplnej ze styropianu,

$-6 \mathrm{~cm}$ zewnętrzna warstwa fakturowa $\mathrm{z}$ betonu,

$-8 \mathrm{~cm}$ warstwa izolacji cieplnej ze styropianu,

$-0,5 \mathrm{~cm}$ warstwa klejowo- zbrojąca.

Dodatkowo $\mathrm{w}$ ścianie otworowej $\mathrm{w}$ otworach okiennych zastosowano w trakcie badań obudowę z wełny mineralnej oraz płyty GK, gdy jednym z celów badań było wskazanie wpływu otworów okiennych na izolacyjność akustyczną przegrody.

\subsection{Opis przeprowadzonych badań i pomiarów}

Wykonane pomiary i badania oparto o wytyczne zawarte w normie PN-EN ISO 140-5 z 1999 r. [3] oraz PN-EN ISO 16283-1:2014-05 [4], w których wskazana jest wprost m.in.: pozycja mikrofonu, pozycja głośnika, liczba pomiarów oraz czas trwania pomiaru (np. dla mikrofonu ruchomego min.15 s). W związku z powyższym do badań wybrano lokal znajdujący się na parterze do którego przegród (szczególnie okien) była możliwa swoboda dostępu. Do pomiarów wykorzystano wszechkierunkowe źródło dźwięku oraz mikrofon ruchomy. Czas prowadzenia pojedynczego pomiaru wynosił $30 \mathrm{~s}$.

Prowadzone badania i pomiary miały na celu sprawdzenie, jaki wpływ na izolacyjność akustyczną ściany zewnętrznej maja zabiegi dociepleniowe. Dlatego pomiary wykonano w dwóch wariantach: przed (rys.3) i po dociepleniu budynku (rys.4) warstwą izolacyjną ze styropianu gr. $8 \mathrm{~cm}$. Każdorazowo podczas pomiarów badano ścianę pełną oraz ścianę okienną (por. rys.1 i 2) w pomieszczeniu pokoju i kuchni. W trakcie badań w celu zminimalizowania wpływu otworów okiennych wprowadzono tymczasowe zabezpieczanie - zasłonięcie okien od strony źródeł dźwięku. Zabieg ten wykonano za pomocą wełny szklanej ISOVER Aku Płyta gr. $75 \mathrm{~mm}$ w dwóch warstwach układanych tak, aby łączenia płyt nie pokrywały się ze sobą, a po dociepleniu budynku w trzech warstwach układanych j.w.. W obu przypadkach jako wierzchnią warstwę zabezpieczającą wełnę zastosowano płytę GK mocowaną do elewacji pianką. 


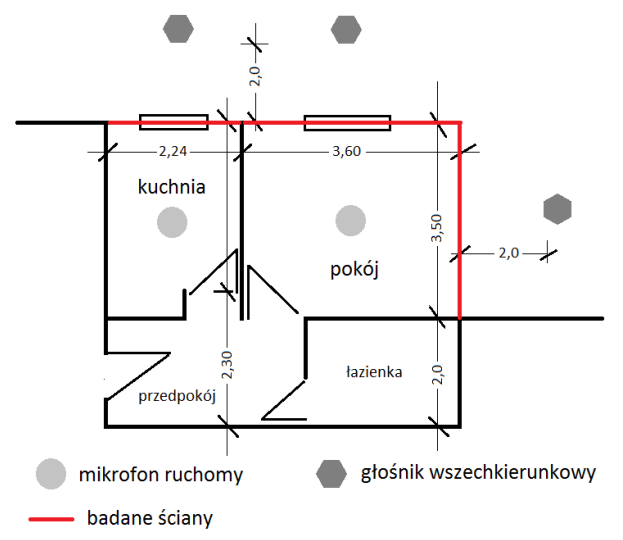

Rys. 1. Rzut lokalu poddanego badaniu

Fig. 1. Arrangement of single Flat

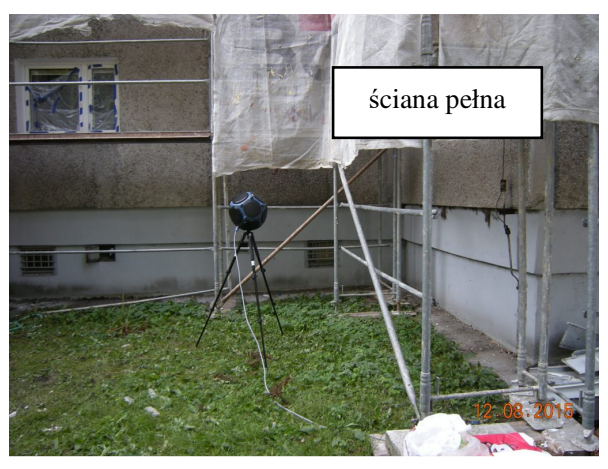

Rys. 3. Źródło dźwięku przy badanej ścianie pełnej przed dociepleniem

Fig. 3. Before thermal insulation

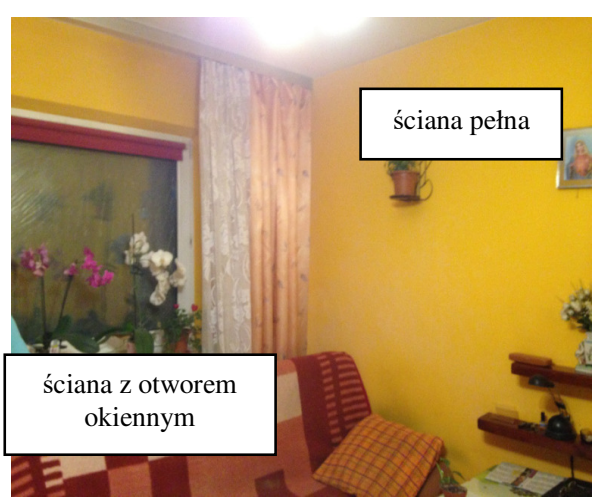

Rys. 2. Widok pokoju w mieszkaniu

Fig. 2. View of internal space

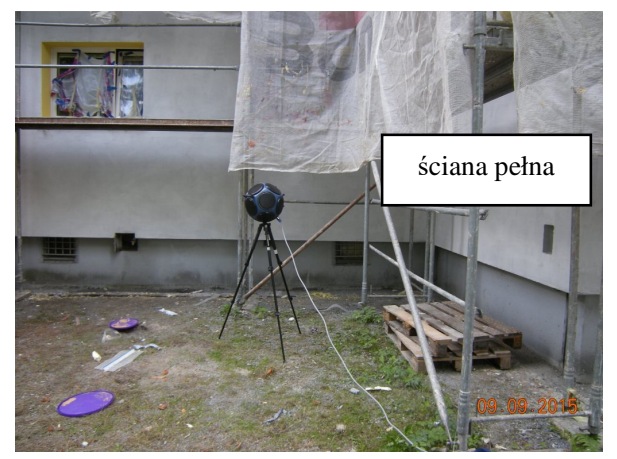

Rys. 4. Źródło dźwięku przy badanej ścianie pełnej po dociepleniu

Fig. 4. After thermal insulation

Badany lokal to mieszkanie typu M4 w skład którego wchodziły 3 pokoje, kuchnia łazienka z WC oraz przedpokój. Analizom poddano przegrody występujące od strony północnej i należące do pokoju i kuchni. Parametry przegród przedstawiały się następująco: pokój pow. $30,87 \mathrm{~m}^{2}$ (okno 170x120 cm), kuchnia pow. $5,49 \mathrm{~m}^{2}$ (okno $140 \times 120 \mathrm{~cm}$ ), wysokość pomieszczeń $2,45 \mathrm{~m}$, ściany zewnętrzne zgodnie $\mathrm{z}$ technologią systemu (por. pkt. 3.1), okna DRUTEX Thermofloat 4x16WESX4 ARGON (rok prod. 2006). Stosunek powierzchni okien do powierzchni ściany wynosi odpowiednio: w pokoju $35 \%$, w kuchni $40 \%$. 


\subsection{Zakres oraz wyniki przeprowadzonych pomiarów}

W takcie powadzonych badań założono i wykonano dwa warianty pomiarów:

- stan istniejący (z nieosłoniętymi i osłoniętymi otworami okiennymi)

- stan po dociepleniu (z nieosłoniętymi i osłoniętymi otworami okiennymi).

Ponadto dla celów porównawczych wykonano pomiar obudowy okiennej. Wyniki z poszczególnych wariantów przedstawiono w tabeli 1.

W kolejnym kroku za pomocą programu dBBati opracowano wyniki pomiarów izolacyjności akustycznej dla poszczególnych ścian i ich wariantów budowy.

Tabela 1. Wyniki izolacyjności akustycznej ścian zewnętrznych

Table 1. The results of acoustic insulation of external walls

\begin{tabular}{|c|c|c|c|c|c|c|}
\hline \multirow{2}{*}{ pom. } & \multirow{2}{*}{ ściana } & \multirow{2}{*}{ zabudowa okna } & \multicolumn{2}{|c|}{$\mathrm{R}^{\prime} 45^{\circ} / \mathrm{R}^{\prime} 45^{\circ} \mathrm{w}[\mathrm{dB}]$} & \multicolumn{2}{|c|}{$\mathrm{R}_{\mathrm{A} 2}^{\prime}[\mathrm{dB}]$} \\
\hline & & & $\begin{array}{c}\text { przed } \\
\text { dociepleniem } \\
\end{array}$ & $\begin{array}{c}\text { po } \\
\text { dociepleniu } \\
\end{array}$ & $\begin{array}{c}\text { przed } \\
\text { dociepleniem } \\
\end{array}$ & $\begin{array}{c}\text { po } \\
\text { dociepleniu } \\
\end{array}$ \\
\hline \multirow[t]{4}{*}{$\begin{array}{c}\text { pokój } \\
30,87 \mathrm{~m}^{3}\end{array}$} & \multirow[t]{2}{*}{$\begin{array}{c}\text { petna } \\
8,82 \mathrm{~m}^{2}\end{array}$} & $\begin{array}{l}\text { wełna ISOVER Aku Płyta gr. } 75 \text { mm } \\
\text { przed dociepleniem: } 2 \text { warstwy + płyta g-k } \\
\text { po dociepleniu: } 3 \text { warstwy + płyta g-k }\end{array}$ & $54(-1 ;-4)$ & $50(-2 ;-3)$ & 50 & 47 \\
\hline & & brak & $49(-1 ;-4)$ & $48(-1 ;-4)$ & 45 & 44 \\
\hline & \multirow{2}{*}{$\begin{array}{l}\text { ściana } \\
\text { z oknem } \\
8,575 \mathrm{~m}^{2}\end{array}$} & wetha mineralna j.w. & $50(-1 ;-3)$ & $49(-1 ;-3)$ & 47 & 46 \\
\hline & & brak & $36(-2 ;-5)$ & $37(-2 ;-4)$ & 31 & 33 \\
\hline \multirow[t]{2}{*}{$\begin{array}{c}\text { kuchnia } \\
17,56 \mathrm{~m}^{3}\end{array}$} & \multirow{2}{*}{$\begin{array}{c}\text { ściana } \\
\text { z oknem } \\
5,49 \mathrm{~m}^{2}\end{array}$} & wetna mineralna j.w. & $54(-1 ;-4)$ & brak badania & 50 & brak badania \\
\hline & & brak & $40(-2 ;-5)$ & $38(-1 ;-2)$ & 35 & 36 \\
\hline
\end{tabular}

Na podstawie przeprowadzonych badań można stwierdzić, że wskaźnik oceny izolacyjności akustycznej właściwej R' ${ }_{\mathrm{A} 2}$ ściany zewnętrznej pełnej (sąsiadującej ze ścianą $\mathrm{z}$ oknem) po dociepleniu jej styropianem gr. $8 \mathrm{~cm}$ zmniejszył się o $1 \mathrm{~dB}$ (z 45dB na 44dB). Natomiast po zaizolowaniu okna w ścianie sąsiedniej wełną mineralną oraz płytami GK, wskaźnik R' $\mathrm{A} 2$ zmniejszył się o $3 \mathrm{~dB}$ (z $50 \mathrm{~dB}$ na $47 \mathrm{~dB}$ ). W przypadku ścian $\mathrm{z}$ oknami zarówno w pokoju jak i w kuchni, wskaźnik $R_{\mathrm{A}, 2}$ po dociepleniu ściany zwiększył się o $1 \div 2 \mathrm{~dB}$ (w pokoju z $31 \mathrm{~dB}$ 
na $33 \mathrm{~dB}$; w kuchni z $35 \mathrm{~dB}$ na $36 \mathrm{~dB}$ ). Natomiast po zaizolowaniu okna wełną mineralną oraz płytami GK wskaźnik R' $\mathrm{A}, 2^{2}$ zmniejszył się o $1 \mathrm{~dB}$ (z $47 \mathrm{~dB}$ na $46 \mathrm{~dB})$.

\section{Wnioski z prowadzonych badań}

Na podstawie dokonanych pomiarów „,in situ” można stwierdzić, że izolacyjność akustyczna ścian zewnętrznych pełnych wykonanych w technologii WUFT-87GT po dociepleniu jej styropianem gr. $8 \mathrm{~cm}$ wyraźnie maleje (por. tab. 1 wiersz 1 i 2), zarówno w przypadku próby zminimalizowania wpływu okien w ścianie sąsiadującej przez zastosowanie wełny mineralnej, jak i bez jego izolacji.

Natomiast w przypadku ścian z otworami prowadzone zabiegi dociepleniowe w nieznacznym stopniu poprawiają izolacyjność akustyczną przegrody zewnętrznej. Po przeprowadzeniu zabiegów dociepleniowych ściany, bez wymiany okna, izolacyjność akustyczna całej przegrody wzrosła (por. tab. 1 wiersz 4 i 6). Ponadto na podstawie prowadzonych badań zauważono zależność pomiędzy powierzchnią okna i przegrody, że w przypadku, gdy stosunek powierzchni okna do powierzchni ściany waha się między $30 \%$ a $45 \%$, izolacyjność całej przegrody wzrasta po jej dociepleniu. Wyjaśnienie tego zjawiska nie jest możliwe na tym etapie badań. Nie ma pewności, czy taki wzrost izolacyjności wystąpi w innych, zbliżonych do tej, sytuacjach, czy jest to przypadek jednostkowy.

Otrzymane wyniki należy traktować jako terenowe badania pilotażowe i wstęp do kolejnych badań w tym kierunku. Niestety ich wykonalność może okazać się dość trudna, gdyż wymaga ona pełnej akceptacji ze strony użytkowników lokali jak również prowadzenia badań w trakcie prac dociepleniowych.

\section{Literatura}

[1] Kłosak A. „Relacje pomiędzy izolacyjnością akustyczną a właściwościami cieplnymi ścian zewnętrznych - wstępne rozpoznanie zagadnienia”, Międzynarodowe seminarium Energodom 2006, Kraków, październik 2006, Czasopismo Techniczne - Budownictwo, z. 5-B/2006, tom II, s. 359-372.

[2] Zębala K., Zastawna-Rumin A., Kłosak A., Dulak L. „Relacje pomiędzy izolacyjnością akustyczną a izolacyjnością termiczną ścian jedno i wielowarstwowych" Międzynarodowa konferencja Energodom 2012, Kraków, wrzesień 2012, Czasopismo Techniczne - Budownictwo, 2-B/2012, s. 471-481.

[3] PN-EN ISO 140-5 z 1999 r. - Pomiar izolacyjności akustycznej w budynkach i izolacyjności akustycznej elementów budowlanych - Pomiary terenowe izolacyjności akustycznej od dźwięków powietrznych ściany zewnętrznej i jej elementów.

[4] PN-EN ISO 16283-1:2014-05 - Pomiary terenowe izolacyjności akustycznej w budynkach i izolacyjności akustycznej elementów budowlanych - od dźwięków powietrznych.

[5] Szudrowicz B. „Budownictwo ogólne” tom 2, Fizyka budowli, rozdz. 8, Arkady. 
[6] ISO 717-1 z 2013 r. Acoustics - Rating of sound insulation in buildings and of building elements - Part 1: Airborne sound insulation.

[7] Ustawa z dnia 7.07.1994 r. Prawo Budowlane, z późniejszymi zmianami.

[8] Rozporządzenie Ministra Transportu, Budownictwa i Gospodarki Morskiej z dnia 12.04.2002 r. w sprawie warunków technicznych, jakim powinny odpowiadać budynki i ich usytuowanie, z późniejszymi zmianami.

\section{MEASUREMENTS OF ACOUSTIC INSULATION IN THE SELECTED EXTERNAL WALLS OF LARGE PANEL BUILDING BEFORE AND AFTER THERMAL MODERNIZATION}

\section{S u m m a r y}

The article presents the results of tests of acoustic insulation of the envelope of the large panel building. The tests were conducted in accordance with applicable standards. The influence of thermal insulation on the acoustic insulation of a single-layer component has been described in many articles. Analyses were performed on the basis of laboratory tests. However, to analyze the impact on the thermal insulation of large panel building external walls on their acoustic insulation, the measurements in the sample apartment were conducted. The study was performed in multi-family residential building built in technology WUFT (cavity wall). Measurements were made in two options: before and after the thermal insulation of walls with $8 \mathrm{~cm}$ thick styrofoam layer. The wall with window framing and the solid wall next to the wall with windows were analyzed. To minimize the impact of windows, measurements were also performed on the insulation of the mineral wool plates arranged in layers alternately. Next the results were presented and analysis made. Thermal insulation affects the sound insulation of the partition. The second part of the analysis in terms of sound insulation was to determine the influence of the windows.

Keywords: acoustic insulation, acoustic pressure, large panels, decibel, WUFT

DOI:10.7862/rb.2016.241

Przestano do redakcji: $30.06 .2016 r$.

Przyjęto do druku: 30.11.2016 r. 